\title{
Tornar-se negro: raça, identidade e biopoder
} Becoming black: race, identity and biopolitcs

\author{
Mario Santos Morel \\ Danichi Hausen Mizoguchi \\ Universidade Federal Fluminense
}

\section{Resumo}

Neste trabalho realizamos um percurso genealógico da raça e do racismo por meio das pesquisas de Michel Foucault sobre o biopoder e a biopolítica e de Achille Mbembe sobre o nascimento do negro e da África no discurso europeu do século XVII. Partimos da tese de que a raça não é uma realidade biológica ou cultural, mas uma invenção política. 0 pensador camaronês evidencia que a condição negra foi matricial para o capitalismo se consolidar como sistema hegemônico e que, no contemporâneo, é a manutenção dessa condição que atualiza nossa colonização. Nesse sentido, gostaríamos de problematizar a raça através da história, explicitar seu uso necropolítico e sua dimensão subjetivante e desejante, a fim de avançar no debate sobre a questão que, a nosso ver, pode ajudar na construção de uma psicologia que se pretende antirracista: quais os modos possíveis de combate à colonização subjetiva?

\section{Palavras-chave: Racismo; Ética; Negro; Subjetividade}

\begin{abstract}
In this work we carry out a genealogical journey of race and racism, through the research of Michel Foucault on biopower and biopolitics and Achille Mbembe on the birth of negro and Africa in the 17th century European discourse. We assume that race is not a biological or cultural reality, but a political invention. The philosophe Cameroonian shows that the black condition was matrix for capitalism to consolidate itself as a hegemonic system and that, in the contemporary, it is the maintenance of this condition that updates our colonization. In this sense, we would like to problematize the race through history, explain its necropolitical use and its subjectivating and desiring dimension to advance the debate with the question that we believe helps in the construction of a psychology that is intended to be anti-racist: what are possible ways to combat subjective colonization?
\end{abstract}

Keywords: Racism; Ethics; Black; Subjectivity 


\section{INTRODUÇÃO}

No presente artigo, partimos da tese de que a colonização, mais do que uma disputa estritamente pátria ou continental, é um processo de subjetivação. Esta afirmação inicial se justifica por outro princípio também caro para nós, que torna indispensável a qualquer análise da subjetividade contemporânea uma investigação sobre as relações de poder: a inseparabilidade entre clínica e política. É em função dessas duas premissas iniciais - sintonizadas com o legado de Frantz Fanon e de outros pensadores de uma clínica antirracista - que nos parece equivocado abordar o tema do racismo, convocado neste dossiê, por uma perspectiva psicologizante, que faz de nossa área uma espécie de "fábrica de interiores" (Baptista, 2000) - isto é, limitarmos nossa investigação apenas às teorias de constituição do sujeito, sem jogar luz sobre os processos históricos de formação do mundo em que vivemos hoje e os efeitos genealógicos que nele incidem. Pensamos que seria igualmente equivocado deixar de fora a dimensão desejante da colonização - porque para nós, amparados nos trabalhos de Gilles Deleuze e Félix Guattari (1972/2010): "O desejo é da ordem da produção; toda produção é ao mesmo tempo desejante e social” (p. 390) -, por mais perversa que ela seja. Assim, em última instância, trataremos de problematizar a raça e o racismo a partir de sua força subjetiva e desejante, procurando interrogar os modos de enfrentamento à violência racial dos quais a psicologia pode e deve participar.

As obras Necropolítica (2011/2017) e Crítica da razão negra (2013/2018), do pensador camaronês Achille Mbembe, nos ajudam a pensar a formação histórica da raça e do racismo e o modo como eles operaram e operam processos político-subjetivos nos países do chamado Sul global. Mbembe foi leitor de livros e cursos de Michel Foucault, e suas pesquisas conversam diretamente com os conceitos foucaultianos de biopoder, racismo de Estado e cuidado de si - notadamente pela dimensão genealógica, que é simultaneamente a ética e a metodologia empregada por ambos em boa parte de suas pesquisas. 0 que pretendemos nesse movimento inicial é discutir as genealogias do racismo intuídas por Foucault e empreendidas por Mbembe, a fim de forjar pistas para sair do labirinto colonial. Nosso percurso conceitual pela obra desses autores não se faz em um gesto exegético de erudição, mas, ao contrário, como tentativa de, através da história, abrir o presente a outras forças e outros modos de existência.

Evidentemente, não pretendemos encerrar a discussão sobre a raça e o racismo, mas provocar novas questões, discussões e inquietações a partir de uma crítica de nós mesmos: avaliar nossos limites históricos e suas ultrapassagens possíveis, como diz Foucault em seu último texto, $O$ que são as Luzes? 
(1984/2000), operando uma clínica do sujeito colonizado, como diz Mbembe (2013/2018) quase ao final de sua Crítica da razão negra. Nesse sentido, na urgência do presente, a pergunta que será o fio condutor deste texto, em consonância com o presente dossiê, é: quais os modos possíveis de combate à colonização subjetiva?

\section{GENEALOGIAS DO RACISMO}

Sustentar as afirmações e interrogações apresentadas na introdução do presente texto significa, para nós, atribuir uma visada genealógica ao problema. É com esta perspectiva inaugurada por Friedrich Nietzsche e desenvolvida por Michel Foucault (1971/1979), que a dimensão subjetiva, segundo nos parece, mergulha na história e torna-se, assim, política. Se a perspectiva genealógica é aquela que entende que o plano temporal é atravessado por forças em embate, continuidade e descontinuidade trata-se, aqui, de investigar as disputas que forjaram a invenção da raça e do racismo para que destes possamos nos desembaraçar.

Foucault encerra o primeiro dos quatro volumes de sua História da sexualidade, a vontade de saber (1976/1988) com um capítulo intitulado "Direito de morte e poder sobre a vida". É ali que aparecem, pela primeira vez em livro, noções que posteriormente se tornariam reiteradas na obra deste autor, como, por exemplo, biopoder e biopolítica. No mesmo ano da publicação deste livro, em 1976, Foucault apresentou no Collège de France um curso cujo título em francês era Il faut défendre la société - cuja tradução mais literal para o português seria "É preciso defender a sociedade", e não "Em defesa da sociedade", como foi publicado no Brasil. O curso chega à América Latina pela primeira vez em uma edição argentina, sob o título de Genealogía del Racismo (Foucault, 1976/1993). Se é verdade que Foucault não foi exatamente um pesquisador nem da raça nem do racismo, não é menos verdade, como indica Edgardo Castro (2014/2015), que, trabalhando as noções de biopoder e biopolítica, esse "curso se apresenta como uma genealogia do discurso da guerra de raças, para mostrar como este último, o conceito de raça, não tem original, nem necessariamente um sentido biológico" (p. 105), mas sim político. É dele, em certa medida, que Mbembe parte em sua crítica das invenções capitalísticas da raça, do negro e da África em Crítica da razão negra (2013/2018).

A parte final do livro e a última aula do curso de Foucault têm estruturas argumentativas semelhantes entre si: ambas são abertas por uma retomada do tema do poder soberano, que já estivera presente nas primeiras páginas de Vigiar e punir (1975/1987) e que implica uma fórmula tão simples quanto assustadora: fazer morrer e deixar viver. 0 rei poderia retirar a vida de quem o de- 
sautorizasse, ou até mesmo mandar seus súditos para uma guerra caso seu reino estivesse ameaçado. Tratava-se de um poder que só se exercia sobre a vida no momento em que matava, quando tinha as devidas justificativas para matar ou quando deixava de matar.

No entanto, Foucault aponta que, a partir do final do século XVIII e início do XIX, ocorre uma transformação profunda na economia de poder. $O$ nascimento do Estado moderno conta com um aparato de tecnologias "com funções de incitação, de reforço de controle, de vigilância, de majoração e de organização das forças que the são submetidas" (Foucault, 1976/1988, p. 148). Um poder que é positivo: "destinado a produzir forças, a fazê-las crescer e a ordená-las mais do que a barrá-las, dobrá-las ou destruí-las" (Foucault, 1976/1988, p. 148). Em outros termos, trata-se de um poder que é da ordem do governo e que "opera sobre o campo de possibilidade onde se inscreve o comportamento dos sujeitos ativos; ele incita, induz, desvia, facilita ou torna mais difícil, amplia ou limita, torna mais ou menos provável" (Foucault, 1995, p. 243). Ou seja: nas relações de poder, trata-se de ações que incidem sobre ações - e essas ações são justamente os gestos que produzem ininterruptamente os nossos modos de existência.

Assim, surge uma configuração do poder constituída pelo imperativo de expansão da vida, de crescimento e maximização das forças cuja execução se traduz pela inversão da fórmula anterior: agora o poder faz viver e deixa morrer. Desse modo, a antiga tecnologia de poder da soberania sofre uma profunda modificação. Não é que ela seja substituída ou anulada, mas sim complementada e refinada. Há um marco, que é o da tomada da vida pelo poder que incide agora sobre o homem enquanto ser vivo, em uma espécie de "estatização do biológico" (Foucault, 1976/2010, p. 286). Assim, o poder soberano - o poder de tirar a vida - se converte em um poder sobre a vida: um biopoder.

O biopoder é constituído por dois eixos complementares e entrelaçados, um individualizante e outro globalizante. 0 primeiro eixo, disciplinar, incide diretamente no corpo individual, principalmente por meio das instituições, como, por exemplo, a fábrica, a escola, o exército, o presídio, o hospital, a família, e tem como objetivo a produção de corpos dóceis, corpos que produzem muito e se rebelam pouco. 0 segundo eixo, biopolítico, tem como alvo o corpo populacional, e seu aparato tem como meta "levar em conta a vida, os processos biológicos do homem-espécie e de assegurar sobre eles (...) uma regulamentação" (Foucault, 1976/2010, p. 294) através de previsões, estimativas estatísticas e medições globais. Com o uso de tecnologias totalmente diferentes, ambos são coincidentes em seus objetivos: a otimização da vida e a extração e maximização das forças. 
$\mathrm{Na}$ leitura foucaultiana, o biopoder foi elemento indispensável para o desenvolvimento do capitalismo. É uma tecnologia que garante o controle dos corpos e sua inserção no aparato produtivo, que adapta os fenômenos de população aos processos econômicos, majora as forças, as aptidões, a vida, e ao mesmo tempo reduz as possibilidades de insurreição. Além disso, suas técnicas espalhadas por todo o tecido social "operaram também como fatores de segregação e de hierarquização social, agindo sobre as forças respectivas tanto de uns como de outros, garantindo relações de dominação e efeitos de hegemonia" (Foucault, 1976/1988, p. 154). A adequação do crescimento da população - e consequentemente da expansão das forças produtivas - à repartição diferencial do lucro e dos bens só foi possível pela valorização e investimento sobre o corpo vivo e pela administração da distribuição das forças produtivas - ou seja, pelo exercício do biopoder.

Mas se o novo regime se faz em prol da vida - se a palavra de ordem volta-se para a otimização e maximização das forças e diminuição e prevenção daquilo que as diminui -, como explicar o fato de que os maiores genocídios presenciados pela humanidade foram contemporâneos ao biopoder? Sob essa perspectiva, como se explicam os extermínios, os holocaustos, as guerras, as bombas atômicas e as colonizações? 0 que possibilita ao exercício do poder causar a morte de maneira tão explicita, em um regime cujo imperativo é a vida?

Foucault afirma que em um diagrama de poder como esse a lógica é paradoxal: só é possível tirar a vida quando isso se faz em nome da vida. Na modernidade, os massacres tornaram-se vitais. Surge, então, uma certa sobreposição de imperativos como política do corpo: fazer viver e fazer morrer (Mizoguchi e Martins, 2019):

O princípio: poder matar para poder viver, que sustentava a tática dos combates, tornou-se princípio de estratégia entre Estados; mas a existência em questão já não é aquela - jurídica - da soberania, é outra - biológica - de uma população. Se o genocídio é, de fato, o sonho dos poderes modernos, não é por uma volta, atualmente, ao velho direito de matar; mas é porque o poder se situa e exerce ao nível da vida, da espécie, da raça e dos fenômenos maciços da população. (Foucault, 1976/1988, p. 148)

Ele alerta que a estratégia de guerra adotada como forma de governo pelos Estados modernos só pode se justificar por meio de um racismo de Estado. Os maiores massacres realizados pela humanidade contra si mesma tiveram como pano de fundo esse delírio de um sangue e de uma raça superior; portanto, a preocupação em proteger a pureza do sangue e fazer triunfar a raça maior não é característica apenas do nazismo. Como diz Foucault (1976/2010) "como se pode fazer um biopoder funcionar e ao mesmo tempo exercer os direitos da 
guerra, os direitos do assassínio e da função de morte, senão passando pelo racismo? Era esse o problema, e eu acho que continua a ser esse o problema" ( $p$. 315). Ele indica, ainda, que, com a emergência do biopoder, não há "funcionamento de Estado que não tenha como ferramenta de governo o racismo" (1976/2010, p. 304) - um racismo de Estado, que é definido da seguinte maneira:

É, primeiro, o meio de se introduzir, afinal, nesse domínio da vida de que o poder se incumbiu, um corte: o corte entre o que deve viver e o que deve morrer. No contínuo biológico da espécie humana, o aparecimento das raças, a distinção das raças, a hierarquia das raças, qualificação de certas raças como boas e de outras, ao contrário, como inferiores, tudo isso vai ser uma maneira de fragmentar esse campo do biológico de que o poder se incumbiu; uma maneira de defasar, no interior da população, uns grupos em relação aos outros. Em resumo, de estabelecer uma cesura que será do tipo biológico no interior de um domínio considerado como sendo precisamente um domínio biológico. Isso vai permitir ao poder tratar uma população como uma mistura de raças ou, mais exatamente, tratar a espécie, subdividir a espécie de que ele se incumbiu em subgrupos que serão, precisamente, raças. Essa é a primeira função do racismo: fragmentar, fazer cesuras no interior desse contínuo biológico a que se dirige o biopoder. (Foucault, 1976/2010, pp. 304-305)

Há, nesta relação íntima entre o racismo, o capitalismo e o Estado, um duplo paradoxo. 0 primeiro é que o racismo de Estado funciona numa relação de otimização da vida: "quanto mais você deixar morrer, mais, por isso, você viverá" (Foucault, 1976/2010, p. 305). Para viver, é preciso que o outro morra. Pela existência biológica da raça superior é preciso eliminar a raça inferior - de acordo com a infame categorização de Arthur de Gobineau, "quem afirmou que as raças protagonizaram as lutas pelo poder e, portanto, haveria raças superiores e raças inferiores" (apud Tenório, 2020, p. 33). Assim, "quanto mais as espécies inferiores tenderem a desaparecer, quanto mais os indivíduos anormais forem eliminados, menos degenerados haverá em relação a espécie - mais viverei, mais forte serei, mais vigoroso serei, mais poderei proliferar" (Foucault, 1976/2010, p. 305). Quanto mais raças inferiores, deficientes, doentes, anormais, forem exterminadas, mais fortes serão - num nível mais global, num nível biopolítico - os normais, os cidadãos de bem. Sob esta lógica, a "morte do outro não é simplesmente a minha vida, na medida em que seria minha segurança pessoal; a morte do outro, a morte da raça ruim, da raça inferior (ou do degenerado, ou do anormal), é o que vai deixar a vida em geral mais sadia; mais sadia e mais pura" (Foucault, 1976/2010 p. 305). É preciso defender a sociedade não de um adversário individual, mas de um adversário biológico que se torna, também, político. 
A segunda parte do paradoxo indica que, pela suposta superioridade de uma determinada raça - ou, por outra, pela suposta pureza de uma determinada raça -, é preciso sujeitar a própria população à morte: expô-la a sacrifícios, misérias, guerras e pandemias, para torná-la mais forte. "Quanto mais numerosos forem os que morrerem entre nós, mais pura será a raça a que pertencemos" (Foucault, 1976/2010, p. 308). Sob o regime do biopoder, o poder de morte não se encontra centralizado na figura do Estado, mas espalhado por todo o campo social. 0 exemplo da Alemanha nazista ilustra bem isso: o poder de morte é pulverizado em diversas instâncias; e, no limite, com a população sendo estimulada a denunciar seus vizinhos, todos podiam matar ou fazer morrer aquele que estava ao seu lado - em nome da nação, da regeneração e do fortalecimento da raça. Nos Estados modernos, a exposição à morte se torna modelo de governo da população. Trata-se de um racismo, portanto, que vai muito além do desprezo das raças entre si - ou das raças ditas superiores pelas ditas raças inferiores: ele se torna indispensável para o funcionamento do capitalismo. À medida que os mecanismos de expansão da vida são utilizados para exercer o poder soberano de matar, a biopolítica se transforma em uma política de morte. Ao atribuirmos a devida gravidade à afirmação de que todos os aparelhos de Estado são racistas e de que o racismo de Estado como modo de governo não se limita apenas ao Estado, que sob o biopoder o direito de tirar a vida se tornou microfísico, espalhado pelo tecido social, se faz necessário indagar sobre a influência desses vetores mortíferos em nós mesmos, hoje, no Sul global de 2021, e insistir na pergunta: quais os modos possíveis de combate à colonização subjetiva?

\section{A INVENÇÃO DO NEGRO}

A tese de Achille Mbembe (2013/2018), simultaneamente seguindo e desviandose de Foucault, indica que o biopoder não nasceu na Europa dos séculos XVIII e XIX, no desenvolvimento das tecnologias de Estado modernas, mas nas colônias de plantation da primeira fase do capitalismo. Para o filósofo camaronês, os territórios colonizados serviram de setting experimental para as técnicas estatais de administração da vida, dos fluxos e da morte: "Qualquer relato histórico do surgimento do terror moderno precisa tratar da escravidão, que pode ser considerada uma das primeiras manifestações da experimentação biopolítica" (Mbembe, 2011/2017, p. 27). Sob essa perspectiva, o Brasil se apresenta como um gigantesco laboratório da simultaneidade do biopoder (política de controle e produção da vida) e da necropolítica (política de controle e produção da morte) desde sua fundação. 
As transformações econômicas da modernidade nascente exigiam uma grande quantidade de mão de obra, a fim de tornar possível uma produção comercializada ao longo de enormes distâncias. Se a questão era como fazer isso, a invenção do negro foi a resposta, como afirma Mbembe (2013/2018). Mais do que a utilização da raça como tecnologia de administração da vida e da morte pelos Estados modernos, a invenção do negro foi condição sine qua non para o capitalismo se consolidar como sistema hegemônico tanto na Europa quanto na relação entre a metrópole e a colônia.

O negro foi de fato o elemento central que, ao permitir a criação, por meio da plantation, de uma das formas mais eficazes de acumulação de riqueza na época, acelerou a integração do capitalismo mercantil, da mecanização e do controle do trabalho subordinado. A plantation representava na época uma grande inovação, e não simplesmente do ponto de vista da privação da liberdade, do controle de mobilidade da mão de obra e da aplicação ilimitada da violência. A invenção do negro também abriu caminho para inovações cruciais nas áreas do transporte, da produção, da comercialização e dos seguros. (Mbembe, 2013/2018, pp. 45-46)

É constitutivo da modernidade o estabelecimento da servidão perpétua das pessoas de origem africana como regra. Até então a colônia tinha um racismo ainda em maturação, não tinha muito bem demarcado um critério racial, isto é, não se escravizavam apenas aqueles de origem africana. Já o século XVII é marcado por um imenso aparato legislativo que visava selar o futuro do sujeito racializado; foi quando se instalou uma série de novas leis que excluíam os africanos e seus descendentes de certos privilégios e direitos assegurados aos outros habitantes da colônia. Quanto ao negro, passou a ser a partir de então nada além de um bem móvel, pelo menos de um ponto de vista estritamente legal" (Mbembe, 2013/2018, p. 45). Portanto, os negros não eram mais como os outros cidadãos; doravante, podiam ser comprados para sempre, tornando-se escravos perpétuos.

Seria errôneo pensar que saímos definitivamente desse regime que teve o comércio negreiro e em seguida a colônia de plantation ou simplesmente extrativista como cenas originárias. Nessas pias batismais da nossa modernidade, pela primeira vez na história humana, o princípio racial e o sujeito de mesma matriz foram operados sob o signo do capital, e é justamente isso que distingue o tráfico negreiro e suas instituições das formas autóctones de servidão. (Mbembe, 2013/2018, p. 33)

O discurso europeu na fase atlântica do capitalismo, em sua soberba racional e "civilizada", classificou e categorizou seus dessemelhantes como selvagens, inferiores evolutivamente, mais próximos ao "estado de natureza" do que de humanidade, e toda uma série de outros adjetivos que produziam uma certa 
hierarquia na qual o cidadão europeu se encontrava no topo. Esse desejo de territorialização, que acompanhou tanto as práticas quanto os enunciados do empreendimento colonial, promoveu o ato de fabulação a partir do qual "nascem e ficam inscritos a África e o negro" (Mbembe, 2013/2018, p. 31). Ambos os signos surgiram em referência não a um nome comum ou próprio, mas, mais precisamente, como o indício de uma ausência: um território com ausência de obra e trabalho, uma coisa viva com ausência de razão e de humanidade.

Grada Kilomba diagnosticou esse ato de fabulação colonial como um mecanismo de defesa do ego ${ }^{1}$. Fantasiava-se que o negro queria roubar algo que pertencia ao seu senhor e que era selvagem, ao mesmo tempo em que se agenciava uma negação ${ }^{2}$ do roubo e da selvageria exercida pelo colonizador europeu. “O sujeito negro torna-se então tela de projeção" (Kilomba, 2008/2019, p. 37) daquilo que o colonizador teme reconhecer em si mesmo.

Entre os séculos XV e XIX, o horizonte espacial da Europa alargou-se progressivamente. O oceano Atlântico tornou-se o lugar de onde emergiu uma nova consciência planetária, onde se criou um novo mundo. Mbembe afirma que a consciência negra nasceu dessa dinâmica de movimento e circulação, numa lógica de desnacionalização da imaginação. "A transnacionalização da condição negra foi, portanto, um momento constitutivo da modernidade, tendo sido o Atlântico o seu lugar de incubação" (Mbembe, 2013/2018, p. 36). É esse o momento no qual as fabulações projetivas gradativamente se internacionalizaram.

No decorrer do período atlântico (...) entraram em cena vários discursos de verdade acerca da natureza, da especificidade e das formas de vida, das qualidades, traços e características dos seres humanos, das populações inteiras diferenciadas em termos de espécies, gêneros ou raças, classificados ao longo de uma linha vertical. (Mbembe, 2013/2018, p. 40)

0 nascimento da sociedade de plantation se deu entre 1630 e 1640 . Vivia-se sob constante regime do medo, governamentalidade muito semelhante à de uma sociedade ou campo paramilitar. Medo molecular da violência física e psicológica do soberano e da possibilidade da violência insurreta do escravo. 0 medo é peça-chave no governo da plantation, e o ódio também: "O negro da

\footnotetext{
${ }^{1} \mathrm{Na}$ obra Memórias da plantação: episódios de racismo cotidiano (Kilomba, 2008/2019), a autora faz uma leitura psicanalítica na qual as partes cindidas da psique colonial são projetadas externamente, criando um "Outro" sempre antagonista do "eu" (self). Aquelas partes do colonizador que não correspondiam a seus ideais egóicos são projetadas em seus dessemelhantes, ficando com ele apenas a "generosidade" civilizacional.

${ }^{2}$ Em psicanálise, negação é o conceito usado para descrever o "processo pelo qual o sujeito, embora formulando um dos seus desejos, pensamentos ou sentimentos até então recalcados, continua a defender-se deles negando que the pertençam". Ver Vocabulário da Psicanálise. Laplanche e Pontalis (1967/2001, pp. 293-295).
} 
plantation era, ademais, aquele que se havia socializado no ódio aos outros e, sobretudo, aos outros negros" (Mbembe, 2013/2018, p. 44).

É nessa mesma época, nesse mesmo espírito iluminista, que os povos e as culturas começaram a ser considerados como individualidades contidas em si mesmas. A identidade nacional brasileira, por exemplo, advêm desse período, no qual nossa terra foi batizada com o nome da árvore que servia como matéria-prima para o corante cor de brasa, uma das primeiras atividades econômicas dos portugueses. Cada comunidade e cada povo passou a ser entendido como um coletivo único; "uma vez identificados e classificados os gêneros, as espécies e as raças, resta apenas indicar quais diferenças os distinguem uns dos outros" (Mbembe, 2013/2018, p. 40). A primeira grande classificação das raças é feita pelo naturalista conde de Buffon ${ }^{3}$ no século XVIII, momento em que a linguagem e o imaginário sobre os mundos para além da Europa eram constituídos a partir de diversos preconceitos e ingenuidades e em que "formas de vida extremamente complexas eram remetidas à pura simplicidade dos epítetos" (Mbembe, 2013/2018, p. 41). E assim surge o negro no discurso racional europeu, descrito e analisado tal como um animal.

A razão negra designa "um conjunto tanto de discursos como de práticas - um trabalho cotidiano que consistiu em inventar, contar, repetir e promover a variação de fórmulas, textos e rituais com o intuito de fazer surgir o negro como sujeito racial e exterioridade selvagem, passível de desqualificação moral e de instrumentalização prática" (Mbembe, 2013/2018, p. 62). 0 racismo, enquanto forma de governamentalidade, para além das práticas de Estado, opera subjetivamente "naquilo que se consola odiando, manejando o terror, praticando o alterocídio, isto é, constituindo o outro não como semelhante a si mesmo, mas como objeto propriamente ameaçador" (Mbembe, 2013/2018, p. 27) do qual é necessário se defender e que se deve até mesmo destruir.

A condição negra é a matriz do capitalismo, e é na manutenção dessa condição que se atualiza a nossa colonização, como bem lembra o pensador camaronês: "Se existe um pequeno segredo na colônia, é certamente a sujeição do nativo por seu desejo" (Mbembe, 2013/2018, p. 211). Partimos aqui do entendimento de que a "raça não existe enquanto fato natural físico, antropológico ou genético" (Mbembe, 2013/2018, p. 28) e de que sempre se transformou de acordo com os interesses do colonizador. Se Mbembe tem razão e o século XXI é o momento da história no qual a condição negra se alastra independentemente do nível de melanina ou de traços ditos africanos, debruçarmo-nos sobre a razão negra e os vetores coloniais torna-se urgente para prosseguirmos em nossa in-

\footnotetext{
${ }^{3}$ Ver Georges-Louis Buffon em “Variétés dans l'espècie humaine” (apud Mbembe, 2013/2018).
} 
vestigação. Nesse sentido, nossa questão insiste com mais força: quais os modos possíveis de combate à colonização subjetiva?

\section{A CLÍNICA DO SUJEITO RACIAL E A ASCESE NEGRA}

A máquina subjetiva colonial e as mortes produzidas pela nossa plantation contemporânea não param. "O tráfico negreiro, a escravidão, a diáspora africana e o genocídio da população negra foram e são tecnologias de uma política de afetos tristes que quis impor um banzo estrutural na sociedade capitalística em que vivemos" (Mizoguchi e Passos, 2019). Banzo ${ }^{4}$ que se faz presente no Brasil há 521 anos, e que tem sua manutenção recente no novo modo de genocídio da população negra: as mortes por sufocamento intencionalmente produzidas pelo governo federal durante a pandemia de covid-19 (Brum, 2020). No entanto, nesse período tão difícil que estamos passando enquanto nação, assolados pela política do "fazer morrer e deixar morrer" (Coimbra, 2021)5, é preciso lembrar das apostas de combate a colonização que encontramos no Brasil desde sua invasão. É na direção de uma outra relação de si consigo e, portanto, com o mundo que nasceram a capoeira, a Umbanda, a feijoada, o acarajé, o samba de roda e o axé music baianos, o rap paulista e o funk carioca, dentre muitos outros. Movimentos que - muito sintonizados com a aposta que Mbembe faz no último capítulo de sua Crítica da razão negra - sustentam o combate a colonização começa na subjetividade.

A pesquisa de Mbembe $(2013 / 2018)$ percorre o modo como a raça e o racismo atuaram como forma de governo e de subjetivação; investiga o nascimento do negro no discurso racional europeu e a apropriação dessa categoria por aqueles que foram subalternizados por ela. Ele lembra que o "nome 'negro' (...) remete (...) a um vínculo de submissão. No fundo, só existe 'negro' em relação a um 'senhor'” (Mbembe, 2013/2018, p. 265). Na mesma direção, a psicanalista portuguesa Grada Kilomba - com raízes em Angola e São Tomé e Príncipe - sustenta que "é preciso (...) colocar-se fora da dinâmica colonial; isto é, é preciso despedir-se daquele lugar de Outridade" (Kilomba, 2008/2019, p. 230). Que fazer, então, com esse nome que nos foi dado pelo colonizador? Que fazer com

\footnotetext{
4 "Banzo é uma expressão que se origina de mbanza, que em quimbundo significa aldeia. Refere-se ao sentimento de melancolia em relação à terra natal e de aversão à privação da liberdade praticada contra a população negra no Brasil notadamente à época da escravidão" (Mizoguchi e Passos, 2019).

${ }^{5}$ Cecilia Coimbra respondendo, quando perguntada sobre o que a motivou a escrever seu livro recém-lançado Fragmentos de Memórias Malditas - Invenção de Si e de Mundos: "O momento que a gente está vivendo, onde imperam o negacionismo, o fascismo e o genocídio planejado. Onde o slogan é 'fazer morrer e deixar morrer'” (Coimbra, 2021).
} 
essa inscrição colonial externa a nós? Será que poderíamos combater a colonização subjetiva recusando a identidade daquilo que dizem que somos?

Gostaríamos de destacar, junto a Mbembe e os outros pensadores negros, que o ajudam a pensar modos de combate à colonização, a experiência estética do axé music. A disputa pela autodeterminação da própria existência e pelo futuro sempre foi central nas lutas dos escravizados. Marcus Garvey (apud Mbembe, 2013/2018) defendia que autodefinir-se pela carência não bastava, "era preciso que o negro se tornasse outro. Fazer-se empreendedor de si mesmo e se transformar num sujeito capaz de se projetar no futuro e se dedicar a um desejo" (p. 267). A direção é de que o negro se autoproduza, "não como repetição, mas como diferença irresolúvel e singularidade absoluta. Da perda e da destruição, haveria de surgir uma potência de formação, substância viva criadora de uma nova forma de mundo" (Mbembe, 2013/2018, p. 267, grifos do autor). 0 exemplo do axé, da materialidade a essas indicações, experiência nascida em Salvador, epicentro da cultura afro-brasileira "talvez seja essa que faça aparecer com mais força a dimensão política da alegria que tanto nos interessa aqui e agora: alegria antibanzo que enfrenta o racismo estrutural em sua fundação afetiva e energética" (Mizoguchi e Passos, 2019). 0 termo axé, como identidade do movimento musical e estético, foi criado pelo jornalista Hagamenon Brito, que batizou pejorativamente o gênero musical que começava a fazer muito sucesso nas rádios no final do século XX. No entanto, "a categoria de acusação se reverte em afirmação positiva graças a essa diretriz política dos levantes minoritários" (Mizoguchi e Passos, 2019). Um deslocamento da injuria à potência.

No pensamento de Aimé Césaire ${ }^{6}$ há uma preocupação com o "homem negro". No entanto, o "homem negro" a que o poeta se refere não é uma categoria identitária de repartição do mundo, mas de afirmação da própria pluralidade e da destituição das categorias coloniais. Afirmar a pluralidade do mundo e militar pela queda da colônia "significa dizer que a Europa não é o mundo, mas apenas uma parte dele" (Mbembe, 2013/2018, p. 273), reabilitando, assim, a singularidade e a diferença. Césaire recusa as visões abstratas do universal. Para ele, o universal é o lugar de uma multiplicidade de singularidades. Não existe universal absoluto, "e a preocupação com o 'homem negro' só tem sentido porque abre caminho a uma outra imaginação da comunidade universal" (Mbembe,2013/2018, p. 274). Tal como os baianos, Césaire também afirmou sua negritude, e para ele esse nome remete não a uma identidade, uma essência, uma realidade biológica ou à cor da pele, mas a uma das formas históricas da condição humana, e assim a palavra também deve ser sinônimo da luta pela

\footnotetext{
${ }^{6}$ Ver Aimé Césaire em Discurso Sobre a Negritude, 1987, p. 113 (apud Mbembe, 2013/2018).
} 
liberdade e da indomável esperança de um mundo por vir. 0 axé music recusa à lógica colonial de maneira muito sintônica, Gerônimo Santana, um dos fundadores do movimento afirma "herdamos o antropofagismo dos nossos antepassados indígenas. Tudo o que vem de fora nós engolimos e transformamos em algo completamente novo" (Santana apud Mizoguchi \& Passos, 2019). Gesto baiano não apenas de recusa da origem e do universal absoluto, mas de afirmação da criação, da deglutição daquilo que fortalece e do parto de novos mundos.

Em Pele negra, máscaras brancas, Frantz Fanon (1952/2008) defendeu que o nome "negro" não passava de uma ficção. Ele insistia na possibilidade de cada ser humano e de cada povo se erguer, andar com os próprios pés, escrever e contar a própria história e se apropriar deste mundo que nos é comum, do qual somos todos herdeiros. Seu projeto de elevação coletiva em humanidade é um combate constante, exige uma mobilização em todos os momentos da vida. Busca incessante pela liberdade que envolva "cada sujeito humano e cada povo num formidável trabalho sobre si e numa luta de morte, com engajamento pleno e a ser assumido como tarefa própria, sem a possibilidade de ser delegada a outros" (Mbembe, 2013/2018, p. 281).

Não sou negro (noir) (...) nem sou um negro (nègre). Negro não é nem meu sobrenome nem meu nome, muito menos minha essência e minha identidade. Sou um ser humano e isso basta. (...) O fato de ser escravo, de ser colonizado, de ser alvo de discriminações ou de toda a sorte de abusos, vexações, privações e humilhações em virtude da cor da pele não muda absolutamente nada nisso. Continuo a ser um humano, por mais intrínseca que seja a violência das tentativas que pretendem me fazer acreditar que não sou. (Mbembe, 2013/2018, p. 91)

Esse movimento deve ser acompanhado de violência, que na obra de Fanon é um conceito tanto político quanto clínico; que faz jus tanto a uma doença de origem política quanto a uma prática de ressimbolização do colonizado na qual está em jogo sua elevação em humanidade quando este descobre que "“a sua vida, a sua respiração, os batimentos do seu coração são os mesmos do colono ou ainda que a pele do colono não vale mais que a pele do nativo'" (Mbembe, $2013 / 2018$, p. 282). A violência do colonizado não é a mesma violência do colonizador: a proposta clínica de Fanon não é a de uma retroalimentação da violência, um estado de guerra constante. Ele caracteriza a violência do colonizador como uma força fundamentalmente necropolítica, animada por uma pulsão genocida molecular presente em todos os cenários da vida, não apenas no modo de governo, mas nos comportamentos, na fala, na agressividade, no despre- 
zo, na humilhação. Uma política do ódio ${ }^{7}$ que opera psiquicamente no colonizado uma foraclusão 8 do futuro (Mbembe, 2013/2018).

Já a violência do colonizado é o oposto da violência colonial. Trata-se de uma violência de defesa sobre a própria vida. Descarga energética com que o homem encurralado, ameaçado e humilhado responde ao mundo que o ataca: afeto primário de sobrevivência exercido a fim de preservar a própria existência. As perguntas que Fanon sustenta são: como transformar "essa efervescência energética e esse banal instinto de conservação numa fala política plena e inteira? Como os revirar numa contravoz afirmativa face a lógica de morte de que a potência ocupante se utiliza? Como fazer deles um gesto emancipador dotado dos atributos de valor, razão e verdade?" (Mbembe, 2013/2018, p. 288).

A recusa violenta da violência imposta é produção de vida. Para Fanon, a violência do colonizado tem uma função desintoxicante e instituinte: afirmar a vida - uma nova humanidade, uma nova linguagem, um novo mundo. Esse projeto exige de nós um combate sem fim, uma luta de vida pela universalidade e comunalidade. 0 importante para o combate à colonização contemporânea, segundo o clínico, é o princípio de que "existe, em todo ser humano, algo que não se pode domar, que não se deixa amansar, que a dominação - pouco importa sob quais formas - não é capaz de eliminar, nem de conter, nem de reprimir, pelo menos não totalmente" (Mbembe, 2013/2018, p. 295). E apostamos, aqui no Brasil, que essa violência pode ser alegre em vez de bélica. Que essa violência pode ser como a axé music e modular a ética, a estética e a política em "uma afetação forjada no mais preciso ponto de encontro entre a devoração e a alegria" (Mizoguchi e Passos, 2019, p. 5).

0 homem amordaçado, posto de joelhos e condenado a berrar, recobra-se a si mesmo, sobe a ladeira e se alça à sua própria altura e à dos outros homens, pela violência, se necessário (...). Ao fazê-lo, reabre, para si mesmo e para a humanidade inteira, começando por seus carrascos, a possibilidade de um diálogo novo e livre entre dois sujeitos humanos iguais, no mesmo lugar onde, outrora, a relação opunha primordialmente um homem (o colono) e seu objeto (o colonizado). De repente, não há mais negro nem branco. Existe um só mundo, finalmente livre do fardo da raça e do qual cada um se torna herdeiro (Mbembe, 2013/2018, p. 291).

\footnotetext{
${ }^{7}$ Ver Frantz Fanon em Os Condenados da Terra, 1961, p. 70 (apud. Mbembe, 2013/ 2018).

${ }^{8} 0$ termo foraclusão foi introduzido por Jaques Lacan, que se refere originalmente ao mecanismo psicótico de exclusão/recusa do significante do horizonte simbólico. Aqui foi utilizado para se referir à exclusão/retirada do futuro da dimensão simbólica do sujeito colonizado pela colonização.
} 
Infelizmente estamos, ainda hoje, muito distantes de nos livramos do fardo da raça. Por mais que compreendamos a ficcionalidade da raça e seu uso necropolítico, parece que ainda por muito tempo seremos convocados a responder por esse nome. Enquanto o racismo não tiver sido dizimado, se faz necessário, em vez de buscar por Wakanda ${ }^{9}$ ou de promover um afrocentrismo ensimesmado, continuar a lutar pelo advento de um mundo outro. 0 questionamento das lutas da negritude sempre foi e ainda é: como pertencer de pleno direito a este mundo que nos é comum? Enquanto tal realidade não for alcançada, será preciso trabalhar com e contra o passado, a fim de produzir uma comunalidade para além das raças (Mbembe, 2013/2018). Talvez nossa tarefa do dia seja, na esteira dos baianos, pegar a injuria, o significante negro e com essa violência alegre "melhor confundi-lo e, com isso, melhor se afastar dele, melhor conjurá-lo e melhor reafirmar a dignidade inata de todo o ser humano" (Mbembe, 2013/2018, p. 299).

O professor camaronês chama esse movimento de ascese, e cita como exemplo uma série de tradições políticas, religiosas e culturais afro-americanas e sulafricanas. Trata-se de um trabalho de criação artística, uma estética da existência muito sintonizada com aquilo que Foucault (2018) em certo momento chamou de espiritualidade (Ver Foucault, 2018, pp. 20-21, 27-29, 36), "visto que uma das funções da arte e da religião é justamente preservar a esperança de sair do mundo tal como foi e tal como é, de renascer para a vida e de renovar a festa" (Mbembe, 2013/2018, p. 299).

Seguindo a pista da ascese, Foucault (1981/2010, p. 349) contribui para nos ajudar a elaborar os modos de combate à colonização em nós. Em 1981, ele anunciou para a juventude gay e militante que temos sempre que desconfiar da tendência de levar a homossexualidade para questões identitárias - tradicionais do pensamento ocidental e, portanto, coloniais -, tais como "quem sou eu?", “qual a verdade do meu desejo?", “qual a verdade sobre mim?". Ele defende que não há verdade a ser desvelada, fundo a ser descoberto, origem a ser buscada, e que é preciso indagar: [quais] "relações podem ser estabelecidas, inventadas, multiplicadas, moduladas?” (1981/2010, p. 349). A psicologia que aqui disputamos - nós, Mbembe, Kilomba, Garvey, Cesairé, Fanon e Foucault - fortalecidos com a magia alegre da Bahia, é a de um modo de vida menor, é a da invenção de novos modos de relação consigo, com os outros, com o mundo, modos polimorfos, diversos, e que cada um tenha sua própria inventi-

${ }^{9}$ Wakanda é um país fictício localizado na África, presente em histórias em quadrinhos e filmes hollywoodianos da Marvel. É o país de origem do super-herói Pantera Negra (que, sob nossa perspectiva, é um Capitão América com outra cor de pele e uniforme, cuja história atualiza novas fabulações sobre a África e o Negro em nome da "representatividade"). 
vidade na direção de um mundo comum. Se o diagnóstico do presente que Mbembe nos ajuda a cartografar é do devir-negro do mundo, pelo qual estamos todos mais ou menos convocados pelo neoliberalismo a uma flexibilização subjetiva em que a margem de elasticidade é sempre definida pelas opções e demandas do mercado, se faz necessário indagar com ainda mais atenção: quais os modos possíveis de combate a colonização subjetiva? Se no contemporâneo "tornar-se outro" é um imperativo do biopoder e da necropolítica, seria possível sustentar um combate à colonização da vida com a mesma estratégia?

O modo como Mbembe (2013/2018) afirma o combate à colonização subjetiva, à clínica do sujeito, é a afirmação da aposta ascética, da aposta em um trabalho inventivo no limite de nós mesmos. Tornar-se outro não por uma demanda colonial, mas para descolonizar a si mesmo e "procurar definir e desenvolver um modo de vida" (Foucault, 1981/2010, p. 351). Afirmação da alegria para espantar o banzo. Nesse sentido, a arte aqui se afasta da representação e se aproxima da criação. Se há um traço marcante da arte negra é o movimento no sentido de levar o sujeito e sua comunidade a saírem do mundo tal como foi e tal como é. Criação da vida e resistência à morte: é disso que se trata a ascese negra, em uma prática estética e clínica - e, portanto, política.

\section{CONSIDERAÇÕES FINAIS}

Neste começo de século, testemunhamos uma massa cada vez maior de homens estruturalmente endividados ao redor do globo, inclusive na Europa. "Desde logo, os riscos sistemáticos aos quais os escravos negros foram expostos durante o primeiro capitalismo constituem agora, se não a norma, pelo menos o quinhão de todas as humanidades subalternas" (Mbembe, 2013/2018, p. 17). A universalização da condição de colonizado vem junto a uma série de práticas imperiais inéditas, herdeiras tanto das lógicas escravagistas de captura e predação - que contam com uma tecnologia de abate cada vez mais sofisticada quanto das lógicas coloniais de ocupação e de exploração, que têm inclusas em seu pacote guerras civis e práticas de devastação. A essa generalização da condição de coisa matável, de mão de obra descartável, de matéria-prima substituível, Mbembe chama devir-negro do mundo.

Tais afirmações são caras para nós, pois ajudam a cartografar a manutenção do jogo colonial e racista, forjado em meados dos séculos XV e XVI, e a atualizá-lo hoje, com as indústrias do silício e suas tecnologias de transmissão, processamento e armazenamento de dados e com o capital financeiro tornando a mão de obra cada vez mais descartável. O cotidiano neoliberal naturalizou cenas de trabalhadores informais pedalando em bicicletas alugadas por aplicativos de celular, entregando pedidos feitos também por aplicativos, tentando bater me- 
tas já não mais estabelecidas pelo patrão. 0 imperativo irônico do presente é que "a melhor coisa do mundo é não ter patrão!" (Gomes, 2019). em uma demanda de produção infinita disfarçada de liberdade individual. Progressivamente vem se estabelecendo uma nova ficção do sujeito humano empreendedor de si mesmo, moldável às demandas do mercado, permanentemente convocado a se reconfigurar diante das novas e ininterruptas convocatórias. 0 sujeito de nosso tempo é condenado "à aprendizagem por toda a vida, à flexibilidade, ao reino do curto-prazo, deve abraçar sua condição de sujeito solúvel e fungível, a fim de atender à injunção que the é constantemente feita - tornar-se um outro" (Mbembe, 2013/2018, pp. 16-17). Porém, como diz Mbembe, se ontem “o drama do sujeito era ser explorado pelo capital, a tragédia da multidão hoje é já não poder ser explorada de modo nenhum, é ser relegada a uma 'humanidade supérflua', entregue ao abandono, sem qualquer utilidade para o funcionamento do capital" (Mbembe, 2013/2018, pp. 15-16).

Sintonizado ao pensamento de Mbembe na direção do futuro, Felwine Sarr (2016/2019) diz que se desejamos hoje "levar a humanidade a um nível diferente daquele onde a Europa a expôs, então teremos de inventar, temos de descobrir" (Sarr, apud Mizoguchi e Passos, 2020) outros modos de existência, aberturas que chamou de "venturosas sínteses" (Sarr, apud Mizoguchi e Passos, 2020).

Venturosas sínteses disjuntivas que, como disseram Deleuze e Guattari (1972/2010), não formam produtos totalizados, mas parciais. Sínteses venturosas que forçam o moderno e the abrem as brechas por onde virtualidades em potencial podem libertar e se libertar, dentre outras coisas, a partir de experiências estéticas e populares. (Mizoguchi e Passos, 2019)

Rearranjando as máquinas desejantes a partir do contágio pela alegria e pela revolução molecular. Outro exemplo que nos ajuda a dar materialidade e proximidade à ascese negra ou às venturosas sínteses disjuntivas são os movimentos das Mães de Maio em São Paulo, das Mães de Manguinhos no Rio de Janeiro e uma série de outros espalhados pelo Brasil que formam uma rede de mulheres que tiveram seus filhos assassinados pelo Estado brasileiro. Redes de mulheres organizadas fazendo resistência à necropolítica, cuidando umas das outras, se fortalecendo e, mesmo com tamanha tragédia biográfica, seguindo na disputa pela vida, se deslocando do luto à luta, afirmando: "somos nós, mães, que vamos parir um Brasil melhor!” (Conectas Direitos Humanos, 2019). Vemos nelas a violência emancipadora do colonizado, o ato de peitar o poder soberano com a própria existência. Estética da existência negra é essa vontade de parir um Brasil outro, essa inventividade de novas redes de mulheres, inventividade de um modo de vida que se choca com o necropoder do Estado brasileiro - cu- 
jo projeto é matar e encarcerar seus descendentes. A implicação de si no jogo político, no jogo de poder, é uma atitude de virar a chave, se deslocar da posição de vítima imóvel e buscar agir na margem, sempre contingente, de liberdade que temos e, portanto, inventar um mundo outro. Porém, a ascética negra é uma empreitada muito arriscada, um combate sem fim e sem garantias. Marielle Franco, a vereadora carioca brutalmente assassinada no Rio de Janeiro, é a prova de que a disputa por uma vida outra pode nos custar a própria vida.

As mães resistentes de nosso tempo, que declaram guerra à casa grande e apostam no parto dum Brasil outro; a alegria contagiante do axé music, são alguns exemplos de que as venturosas sínteses disjuntivas da negritude, são a luta cotidiana contra a colonização e pela invenção de um mundo outro.

\section{REFERÊNCIAS}

Baptista, Luis Antonio dos S. (2000). A fábrica de interiores: a formação psi em questão. EdUFF.

Brum, Eliane (2020, 22 de julho). Há indícios significativos para que autoridades brasileiras, entre elas o presidente, sejam investigadas por genocídio. El País.

https://brasil.elpais.com/brasil/2020-07-22/ha-indicios-significativos-para-queautoridades-brasileiras-entre-elas-o-presidente-sejam-investigadas-porgenocidio.html

Castro, Edgardo (2014/2015). Introdução a Foucault (Tradução de Beatriz de Almeida Magalhães). Autêntica.

Coimbra, Cecilia (2021,10 de abril). Não tenho mais ilusão de revolução. Minha afirmação é a vida cotidiana. Carta Capital. https://www.cartacapital.com.br/sociedade/nao-tenho-mais-ilusao-de-revolucaominha-afirmacao-e-a-vida-cotidiana/

Conectas Direitos Humanos (2018, dezembro 27). SUR 28 - Luto para nós é verbo (documentário). https: / /www.youtube.com/watch?v=nez1MQAYCf8

Deleuze, Gilles \& Guattari, Felix (1972/2010). O Anti-Édipo (Tradução de Luiz. B. L. Orlandi). Editora 34.

Fanon, Frantz (1952/2008). Pele negra, máscaras brancas. Tradução de Raquel Camargo e Sebastião Nascimento. Edufba.

Foucault, Michel (1971/1979). Nietzsche, a genealogia e a história. In: Roberto Machado (Org. e Trad.), Microfísica do poder (p. 15) Edições Graal.

Foucault, Michel (1975/1987). Vigiar e punir: nascimento da prisão. Vozes.

Foucault, Michel (1976/1988). História da Sexualidade I: a vontade de saber (Tradução de Maria Thereza da Costa Albuquerque e José Augusto Guilhon Albuquerque). Graal.

Foucault, Michel (1976/1993). Genealogia del racismo (Tradução de Alfredo Tzveibel). Editorial Allamira. 
Foucault, Michel (1976/2010). Em defesa da sociedade. Martins Fontes.

Foucault, Michel (1981/2010). A amizade como modo de vida. In: Manoel B. da Motta (Org.). Ditos e escritos, vol. VI. (Tradução de Ana Lúcia Paranhos Pessoa, pp. 348353). Forense Universitária.

Foucault, Michel (1984/2000). O que são as Luzes? In: Manoel B. da Motta (Org.), Ditos e Escritos, vol. Il: arqueologia das ciências e história dos sistemas de pensamento (pp. 335-351). Forense Universitária.

Foucault, Michel (1995). Sobre a genealogia da ética: uma revisão do trabalho. In: Hubert Dreyfus e Paul Rabinow (Orgs.), Michel Foucault: uma trajetória filosófica (para além do estruturalismo e da hermenêutica) (pp. 231-251). Forense Universitária.

Foucault, Michel (2018). O enigma da revolta: entrevistas inéditas sobre a Revolução Iraniana (Tradução de Lorena Balbino). N-1 edições.

Gomes, Marcelo. (Diretor). (2019). Estou Me Guardando Para Quando o Carnaval Chegar. Streaming- Netflix. Brasil. Vitrine Filmes.

Kilomba, Grada (2008/2019). Memórias da plantação: episódios de racismo cotidiano. Editora Cobogó.

Laplanche, Jean \& Pontalis, Jean-Bertrand Lefebvre (1867/2001). Vocabulário da psicanálise. Martins Fontes.

Mbembe, Achille (2011/2017). Necropolítica. N-1 edições.

Mbembe, Achille (2013/2018). Crítica da razão negra. N-1 edições.

Mizoguchi, Danichi H. \& Martins, Beatriz A. (2019). Fazer viver, fazer morrer: políticas do corpo. In: Nilton Milanez, Ricardo Amaral \& Ismarina Moura (Orgs.), Transexualidades: o que pode o corpo? (pp. 156-166) Marca de Fantasia.

Mizoguchi, Danichi H. \& Passos, Eduardo. (2019). Axé music: imanência, potência e a alegria. Revista Landa, 8, https://repositorio.ufsc.br/handle/123456789/218529

Sarr, Felwine (2016/2019). Afrotopia. N-1 edições.

Tenório, Jeferson (2020). O avesso da pele. Companhia das Letras.

\section{MARIO SANTOS MOREL}

Psicólogo Clínico e Mestrando no Programa de Pós-Graduação em Psicologia da Universidade Federal Fluminense.

morel96@hotmail.com 


\section{DANICHI HAUSEN MIZOGUCHI}

Professor Adjunto do Departamento de Psicologia da Universidade Federal Fluminense e do Programa de Pós-Graduação em Psicologia da Universidade Federal Fluminense.

danichihm@hotmail.com

FORMATO DE CITACIÓN

Morel, Mario \& Mizoguchi, Danichi (2021). Tornar-se negro: raça, identidade e biopoder. Quaderns de Psicologia, 23(3), e1758.

https://doi.org/10.5565/rev/qpsicologia. 1758

HISTORIA EDITORIAL

Recibido: 26-01-2021

$1^{\mathrm{a}}$ revisión: 10-04-2021

$2^{\mathrm{a}}$ revisión: 21-04-2021

Aceptado: 27-04-2021

Publicado: 25-01-2022 